\title{
The Effect of Problem-based Learning and Mathematical Problem Posing in Improving Student's Critical Thinking Skills
}

\section{Darhim}

Prof., Universitas Pendidikan Indonesia, Bandung, Indonesia, darhim@ upi.edu

\section{Sufyani Prabawanto}

Dr., Universitas Pendidikan Indonesia, Bandung, Indonesia, sufyani@upi.edu

\section{Bambang Eko Susilo}

Universitas Negeri Semarang, Semarang, Indonesia, bambang.mat@mail.unnes.ac.id

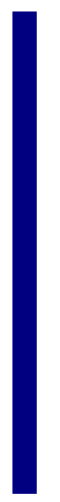

This study aims to determine whether there was differences effect in improving student's critical thinking skills (1) between students who get Problem-based Learning, Mathematical Problem Posing, and conventional learning, and (2) based on gender differences. This study used a quantitative method with the pre-test-posttest two treatment design. Data were collected using instruments: test, documentation, and observation. Data was taken from 124 undergraduate students from the mathematics education study program at Universitas Negeri Semarang, Indonesia. Data analysis was done by using the normalized gain and the MannWhitney test. The results showed that in improving student's critical thinking skills (1) Problem-based Learning and Mathematical Problem Posing provide better effect than conventional learning, (2) there was no significant difference in effect between Problem-based Learning and Mathematical Problem Posing, and (3) there was no significant difference in effect based on gender differences.

Keywords: critical thinking skills, improvement, problem-based learning, mathematical problem posing, gender

\section{INTRODUCTION}

Critical thinking skills are the main skills in the framework of 21 st-century skills along with problem-solving skills, creativity, and innovation, as well as communication and collaboration. Critical thinking ability as a high-level thinking ability is needed to solve problems in mathematics and complex problems in the lives of multinational and multicultural relationships. Future work requires at least 10 (ten) of the following skills: complex problem solving, critical thinking, creative, community management, coordination, emotional intelligence, making judgments and decisions, service-oriented,

Citation: Darhim, Prabawanto, S., \& Susilo, B. E. (2020). The Effect of Problem-based Learning and Mathematical Problem Posing in Improving Student's Critical Thinking Skills. International Journal of Instruction, 13(4), 103-116. https://doi.org/10.29333/iji.2020.1347a 
negotiating, and thinking flexibly (Gleason, 2018). Critical thinking is one of the main keys in developing other skills, it is the result of a long learning process.

Critical thinking skills are part of high-order thinking skills (Trilling \& Fadel, 2009; FitzPatrick \& Schulz, 2015) that requires thinking activities of analyzing, evaluating, and making conclusions (Paul \& Elder, 2014; Asyari et al., 2016; Widiawati et al., 2018). Students in solving problems not only need to understand the materials but also need to making an analysis or clarification of the data provided (clarification), giving an evaluation or evaluate by giving reasons or examples (assessment), making conclusions or inferences (inference), and making problem-solving strategies (strategies) (Perkins \& Murphy, 2006; Vong \& Kaewurai, 2017; Susilo et al., 2019). The success of developing critical thinking skills in learning mathematics is influenced by the choice of models, approaches, and learning strategies used in developing students' critical thinking skills. The ability to think critically has been attempted to develop with various forms of models, approaches, learning strategies, including the Problem-based Learning (Şendağ \& Ferhan Odabaşi, 2009; Alrahlah, 2016; Gholami et al., 2016) and Mathematical Problem Posing (Bonotto, 2013).

Problem-based learning is a learning model that provides real-world problems to students to facilitate learning about critical thinking skills and problem-solving, and to acquire important knowledge and concepts from the lecture material. Problems must be given to students when Problem-based learning is implemented (Chen \& Chang, 2014; Alrahlah, 2016). Problem-based learning steps include: (1) students are given problems by the teacher, (2) students hold discussions in small groups, (3) students conduct studies independently relating to problems that must be solved, (4) students return to the original group to exchange information, peer learning, and cooperate in solving problems, (5) students present the solutions they find, and (6) students are assisted by the teacher to do an evaluation related to all learning activities (Barrett et al., 2005; Gorghiu et al., 2015; Alrahlah, 2016). Specifically, the problem-based learning process in its theory supports the development of critical thinking skills based on applied designs but requires a long term in developing students' critical thinking skills (Masek \& Yamin, 2011). Critical thinking skills can be developed through discussions (Schoenberger-Orgad \& Spiller, 2014), and presenting the problem that can be applied using Problem-based Learning model (Schechter, 2011; Saputra et al., 2019).

Mathematical Problem Posing is a learning model that generates problems or new mathematical questions or reformulates a problem or mathematical question from a problem or mathematical question that has been given. Mathematical Problem Posing steps include: (1) Choosing a starting point; (2) Listing attributes (registering properties); (3) What-if-not-ing (the question "what if not?"); (4) Question asking or problem posing, and (5) Analyzing the problem (analyzing the problem); after analyzing it then they finish it (Brown \& Walter, 2005). Mathematical Problem Posing can encourage students' mathematical thinking (Silver, 2013) and provides an opportunity to interpret and analyze a reality critically (Bonotto, 2013).

Problem posing activities provide many benefits to mathematical achievement, problemsolving skills, the level of problems posed, and attitudes towards mathematics (Rosli et 
al., 2014). Asking students to analyze the problems they make in Mathematical Problem Posing can facilitate students' critical thinking skills because they feel free to discuss the validity of the problem, consider different assumptions, and decide whether the problem has been resolved or not (Bonotto, 2013).

There are three types of problem posing, posing can occur before, during, or after the solution of a problem (Silver, 1994) A problem can be modified in several ways, including: (1) change the information or data on the previous problem, (2) add information or data on the previous problem, (3) change the value of data, but still preserve the condition or situation of the previous problem, (4) change the situation or condition of the previous problem, but still preserve the data or information on the previous problem (Suarsana et al., 2019).

In addition to paying attention to the model, approach, and learning strategies, other factors that need to be considered in developing critical thinking skills are gender factors. Differences in biological growth, such as in terms of gender, are important factors in developing students' critical thinking skills (Ramdiah \& Corebima, 2014). Previous research results show that gender differences have a significant influence on students' critical thinking (Ricket \& Rudd, 2004; Azizmalayeri, et al., 2012). This is evidenced by gender differences affecting the scores of respondents' critical thinking (Ricketts \& Rudd, 2004; Mahanal, 2012). But in other studies, it was shown that there was no influence on respondents' thinking skills in terms of gender differences (Thompson, et al., 2000; Çimer, et al., 2013). These different results are interesting things to be studied together in this study.

\section{Issues and Aims of the Research}

Based on the introduction described above, the issues of this research were (1) whether Problem Based Learning, Mathematical Posing Problems, and conventional learning, have different effects in improving critical thinking skills, and (2) whether based on gender differences have different effects in improving critical thinking skills. Based on the issues, this research has the purpose to determine whether there were differences effect on improving student's critical thinking skills (1) between students who get Problem-based Learning, Mathematical Problem Posing, and conventional learning, and (2) based on gender differences.

\section{METHOD}

\section{Research Design}

This research was an experimental research with the pretest-post-test two treatment design shown in Figure 1 (Cohen et al., 2007). The sample consisted of three groups, two experimental groups, and one control group. The sample consisted of three groups, two experimental groups, and one control group. Before treatment the three groups were given a pretest $(\mathrm{O})$, then the experimental group 1 was treated with the Problem-based Learning (X1), the experimental group 2 was treated with the Mathematical Problem Posing (X2), while the control group was with conventional learning. After being given 
treatment, all three groups were given a posttest $(\mathrm{O})$, so that the improvement in critical thinking skills of the three groups could be determined.

$\begin{array}{llll}\text { Experimental 1 } & \mathbf{O} & \mathbf{X}_{1} & \mathbf{O} \\ \text { Experimental 2 } & \mathbf{O} & \mathbf{x}_{2} & \mathbf{O} \\ \text { Control } & \mathbf{O} & - & \mathbf{O}\end{array}$

Figure 1

The Pre- and Post-Test Two Treatment Design

\section{Participants, Sampling, and Data Analysis}

Participants in the research were first-year mathematics education study program students at Universitas Negeri Semarang, Indonesia. The sample in this research were 124 undergraduate students, 42 students in experimental group 1, 39 students in experimental group 2 , and 43 students in the control group. The sampling technique was purposive sampling while the data analysis was done by using the normalized gain and Mann-Whitney test.

The measurement of increasing the achievement of critical thinking skills used the normalized gain with categories in Table 1 (Hake, 1998).

Table 1

The Normalized Gain Categories

\begin{tabular}{lll}
\hline Gain Scores & Gain Percentage & Categories \\
\hline $0.7 \leq \mathrm{x} \leq 1$ & $70 \leq \mathrm{x} \leq 100$ & High-g \\
$0.3 \leq \mathrm{x}<0.7$ & $30 \leq \mathrm{x}<70$ & Medium-g \\
$0 \leq \mathrm{x}<0.3$ & $0 \leq \mathrm{x}<30$ & Low-g \\
\hline
\end{tabular}

\section{Research Instruments}

This research used instruments: test, documentation, and observation. The test is used as pre-test and post-test to determine the achievement of students' critical thinking skills. This test of mathematics critical thinking skills has been tested before, contains four valid items and has a reliability of 0.702 . Each item represents an indicator of critical thinking skills. The indicators of critical thinking skills used were analyzing problems, concluding and giving explanation, evaluating, and choosing problem-solving strategies. The documentation used was video during lectures. Documentation and observation are used to obtain an overview or description of the conditions of learning and students. The description obtained is then developed exploratively.

\section{FINDINGS}

This research applied Problem-based Learning in experimental group 1, Mathematical Problem Posing in experimental group 2, and conventional learning in the control group. The research data were in the form of pretest and posttest scores were analyzed by using the normalized gain and Mann-Whitney test. 
Table 2

The Results of Pretest and Posttest of Critical Thinking Skills

\begin{tabular}{llllllll}
\hline & \multirow{2}{*}{$\mathrm{N}$} & \multicolumn{3}{l}{ Pretest } & \multicolumn{5}{c}{ Posttest } \\
\cline { 3 - 8 } & & Min & Max & Average & Min & Max & Average \\
\hline Problem-based Learning & 42 & 10 & 65 & 31.07 & 27.5 & 100 & 66.67 \\
Mathematical Problem Posing & 39 & 5 & 85 & 29.81 & 20 & 100 & 63.65 \\
Conventional Learning & 43 & 5 & 60 & 29.83 & 22.5 & 82.5 & 55.23 \\
\hline
\end{tabular}

Table 2 showed that pretest and posttest data are respectively as many as 124 students, 42 students in Problem-based Learning, 39 students in Mathematical Problem Posing, and 43 students in Conventional Learning. The average pretest score in Problem-based Learning is 31.07 while the average posttest score is 66.67 . The average pretest score in Mathematical Problem Posing is 29.81 while the average posttest score is 63.65 . The average pretest score in Conventional Learning is 29.83 while the average posttest score is 55.23. The next pretest and posttest data were used to get the normalized gain scores. The normalized gain scores are used as a percentage to find out the categories of improving critical thinking skills.

Table 3

The Normalized Gain Percentage of Critical Thinking Skills Improvement

\begin{tabular}{lllll}
\hline & \multicolumn{4}{l}{ The Normalized Gain Percentage } \\
\cline { 2 - 5 } & Min & Max & Average & Average Category \\
\hline Problem-based Learning & 7.14 & 100 & 52.84 & Medium \\
Mathematical Problem Posing & 0 & 100 & 49.56 & Medium \\
Conventional Learning & 0 & 67.86 & 36.15 & Medium \\
\hline
\end{tabular}

Table 3 showed that improvement in students' critical thinking skills is known by the average of the normalized gain percentage. The improvement in the Problem-based Learning group was 52.84 in the medium category. The improvement in the Mathematical Problem Posing group was 49.56 in the medium category. The improvement in the Conventional Learning group was 36.15 in the medium category. The next step, to determine the differences in improvement in critical thinking skills between students who got Problem-based Learning, Mathematical Problem Posing, and conventional learning, is to test the difference in the average of the normalized gain percentage. Testing this difference using Mann-Whitney test because there were abnormal data as shown in Table 4.

Table 4

The Results of Tests of Normality

\begin{tabular}{lllll}
\hline \multirow{2}{*}{ Group } & \multicolumn{3}{l}{ Shapiro-Wilk } & \\
\cline { 2 - 5 } NGain Percentage & Statistic & df & Sig. \\
\hline & Conventional Learning & .980 & 43 & .656 \\
& Problem-based Learning & .930 & 42 & .013 \\
& Mathematical Problem Posing & .974 & 39 & .481 \\
\hline
\end{tabular}

Table 4 showed that with the Shapiro-Wilk test, the data in the Problem-based Learning group is not normal, indicated by obtaining Sig. 0.013 less than 0.05 . The first stage of 
the average difference test is to test the difference in the average of the normalized gain percentage between Problem-based Learning group and conventional learning group using Mann Whitney test.

Table 5

The Results of Mann Whitney test between Problem-based Learning Group and Conventional Learning Group

\begin{tabular}{ll}
\hline & NGain Percentage \\
\hline Mann-Whitney U & 618.000 \\
Asymp. Sig. (2-tailed) & .012 \\
\hline
\end{tabular}

Table 5 showed that with the Mann Whitney test, there was significant difference improvement in critical thinking skills between students who got Problem-based Learning and students who got conventional learning, indicated by obtaining Asymp. Sig. (2-tailed) 0.012 less than 0.05 . Because the average of the normalized gain percentage of critical thinking skills improvement in Problem-based Learning (52.84) more than in conventional learning (36.15), it can be concluded that the improvement in critical thinking skills of students who got Problem-based Learning better than students who got conventional learning. The second step is to test the average of the normalized gain percentage difference between Mathematical Problem Posing group and conventional learning group.

Table 6

The Results of Mann Whitney test between Mathematical Problem Posing Group and Conventional Learning Group

\begin{tabular}{ll}
\hline & NGain Percentage \\
\hline Mann-Whitney U & 595.000 \\
Asymp. Sig. (2-tailed) & .024 \\
\hline
\end{tabular}

Table 6 showed that with the Mann Whitney test, there was significant difference improvement in critical thinking skills between students who got Mathematical Problem Posing and students who got conventional learning, indicated by obtaining Asymp. Sig. (2-tailed) 0.024 less than 0.05 . Because the average of the normalized gain percentage of critical thinking skills improvement in Mathematical Problem Posing (49.56) more than in conventional learning (36.15), it can be concluded that the improvement in critical thinking skills of students who got Mathematical Problem Posing better than students who got conventional learning. The third step is to test the difference in the average of the normalized gain percentage between Problem-based Learning group and Mathematical Problem Posing group.

Table 7

The Results of Mann Whitney test between Problem-based Learning Group and Mathematical Problem Posing Group

\begin{tabular}{ll}
\hline & NGain Percentage \\
\hline Mann-Whitney U & 763.000 \\
Asymp. Sig. (2-tailed) & .596 \\
\hline
\end{tabular}


Table 7 showed that with the Mann Whitney test, there was no significant difference improvement in critical thinking skills between students who got Problem-based Learning and students who got Mathematical Problem Posing, indicated by obtaining Asymp. Sig. (2-tailed) 0.596 more than 0.05.

Table 8

The Results of Pretest and Posttest of Critical Thinking Skills based on Gender

\begin{tabular}{llllllll}
\hline & \multirow{2}{*}{$\mathrm{N}$} & Pretest & \multicolumn{3}{c}{ Posttest } \\
\cline { 3 - 8 } & & Min & Max & Average & Min & Max & Average \\
\hline Male & 23 & 5 & 60 & 30.33 & 20 & 100 & 60.11 \\
Female & 101 & 5 & 85 & 30.35 & 27.5 & 100 & 62.40 \\
\hline
\end{tabular}

Table 8 showed that data of pretest and posttest of critical thinking skills based on gender are respectively as many as 124 students, 23 male students, and 101 female students. The average pretest score of male students is 30.33 , while the average posttest score is 60.11 . The average pretest of female students is 30.35 , while the average posttest score is 62.40. The next pretest and posttest data were used to get the normalized gain scores which will be used as a percentage to find out the categories of improving critical thinking skills.

Table 9

The Normalized Gain Percentage of Critical Thinking Skills Improvement based on Gender

\begin{tabular}{lllll}
\hline & \multicolumn{4}{l}{ The Normalized Gain Percentage } \\
\cline { 2 - 5 } & Min & Max & Average & Average Category \\
\hline Male & 3.33 & 100 & 45.19 & Medium \\
Female & 0 & 100 & 46.21 & Medium \\
\hline
\end{tabular}

Table 9 showed that the improvement in critical thinking skills of male students was 45.19 in the medium category. The improvement in critical thinking skills of female students was 46.21 in the medium category. The next step, to determine the differences in improvement in critical thinking skills between male and female students, is to test the difference in the average of the normalized gain percentage. Testing this difference using the Mann-Whitney test because there were abnormal data as shown in Table 10.

Table 10

The Results of Tests of Normality

\begin{tabular}{lllll}
\hline & Group & Shapiro-Wilk & \\
\cline { 3 - 5 } NGain Percentage & Male & .980 & df & Sig. \\
& Female & .960 & 23 & .899 \\
\end{tabular}

Table 10 showed that with the Shapiro-Wilk test, the data of female students is not normal, indicated by obtaining Sig. 0.004 less than 0.05 . The next stage of the average difference test is to test the difference in the average of the normalized gain percentage between male and female students using the Mann-Whitney test. 
Table 11

The Results of Mann Whitney test between Male and Female Students

\begin{tabular}{ll}
\hline & NGain Percentage \\
\hline Mann-Whitney U & 1153.000 \\
Asymp. Sig. (2-tailed) & .956 \\
\hline
\end{tabular}

Table 11 showed that with the Mann-Whitney test, there was no significant difference improvement in critical thinking skills between male and female students, indicated by obtaining Asymp. Sig. (2-tailed) 0.956 more than 0.05 .

\section{DISCUSSION}

Critical thinking skills improvement in problem-based learning, mathematical problem posing, and conventional learning

Based on Table 3, it can be seen that the improvement of critical thinking skills in Problem-based Learning group, Mathematical Problem Posing group, and Conventional Learning group in the medium category. Based on Table 3, it can be seen that the normalized gain percentage of critical thinking skills improvement in Problem-based Learning is 52.84 and in Conventional Learning is 36.15. Based on the results of the Mann-Whitney test in Table 5, it is known there was a significant difference improvement of critical thinking skills between students who got Problem-based Learning and students who got conventional learning. Because the average 52.84 more than 36.15, it can be concluded that the improvement in critical thinking skills of students who got Problem-based Learning better than students who got conventional learning.

Problem-based Learning provides more opportunities for students to be more active in solving problems given, both individually and in small groups. Furthermore, as Problem-based Learning syntax, in the learning process students are given facilities to discuss, exchange knowledge, peer learning, work together in solving problems, and present solutions they find (Barrett et al., 2005; Gorghiu et al., 2015; Alrahlah, 2016). This has implications for students to always think of analyzing, evaluating, concluding, and formulating strategies in solving problems, which are indicators of critical thinking skills (Dwyer et al., 2014; Schoenberger-Orgad \& Spiller, 2014; Samejima et al., 2015; Fajrianthi et al., 2016; Susilo et al., 2018). The thinking process has a significant impact on developing students' critical thinking skills (Şendağ \& Ferhan Odabaşi, 2009; Gholami et al., 2016). As a result, the improvement in the critical thinking skills of students who got Problem-based Learning better than students who got conventional learning. Based on these results it can be said that Problem-based Learning provides a better effect than conventional learning in improving student's critical thinking skills.

Based on Table 3, it can be seen that the normalized gain percentage of critical thinking skills improvement in Mathematical Problem Posing is 49.56 and in Conventional Learning is 36.15. Based on the results of the Mann-Whitney test in Table 6, it is known there was significant difference improvement in critical thinking skills between students who got Mathematical Problem Posing and students who got conventional learning. 
Because the average 49.56 more than 36.15 , it can be concluded that the improvement in critical thinking skills of students who got Mathematical Problem Posing better than students who got conventional learning.

Mathematical Problem Posing indirectly forces students to understand problems through the process of generating new problems. Formulation of the problem is the first step in problem-solving, namely understanding the problem given (English, 1997). The process of question asking or problem-posing begins with analyzing the problem given, then students list attributes or registering properties of the problem. Then the students evaluate it with "What-if-not-ing" or "What-if-not?", what if the attributes or properties of the problem are not met or in other conditions. "What if not?" technique has the same value as "looking back" in solving problems in one's solution to mathematical problems to produce new insights (Silver, 2013). Then students will be able to ask a question or problem posing, then analyze the problem and develop a problem-solving strategy both individually and in groups. These activities support students to always think of analyzing, evaluating, concluding, and formulating strategies in solving problems, which are indicators of critical thinking skills. This process has an impact on improving students' critical thinking skills (Rosli et al., 2014), so it's better than students who got conventional learning (Mahmuzah et al., 2014; Juano \& Pardjono, 2016). Based on these results it can be said that Mathematical Problem Posing provides a better effect than conventional learning in improving student's critical thinking skills.

Based on Table 3, it can be seen that the normalized gain percentage of critical thinking skills improvement in Problem-based Learning is 52.84 and in Mathematical Problem Posing is 49.56. Based on the results of the Mann-Whitney test in Table 7, it is known there was no significant difference improvement in critical thinking skills between students who got Problem-based Learning and students who got Mathematical Problem Posing. It can be concluded that critical thinking skills improvement in Problem-based Learning and Mathematical Problem Posing have the same condition. Problem-based Learning and Mathematical Problem Posing both have learning steps that are capable of impacting the process of analyzing problems, concluding and giving explanation, evaluating, and choosing problem-solving strategies which are indicators of critical thinking skills, so critical thinking skills improvement in Problem-based Learning and Mathematical Problems Posing is generated in the same condition.

Based on the normalized gain percentage in Table 3 and the results of Mann Whitney test in Table 5, Table 6, and Table 7, it can be concluded that (1) improvement in critical thinking skills of students who get Problem-based Learning and Mathematical Problem Posing better then students who get conventional learning and (2) there was no significant difference improvement in critical thinking skills between students who got Problem-based Learning and students who got Mathematical Problem Posing. In other words, in improving student's critical thinking skills (1) Problem-based Learning and Mathematical Problem Posing provide better effect than conventional learning and (2) there was no significant difference in effect between Problem-based Learning and Mathematical Problem Posing. 


\section{Critical thinking skills improvement based on gender}

Based on Table 9, it can be seen that the improvement of critical thinking skills of male and female students in the medium category. It can be seen that the normalized gain percentage of critical thinking skills improvement of male students is 45.19 and female students is 46.21. Based on the results of the Mann-Whitney test in Table 11, it is known there was no significant difference improvement in critical thinking skills between male and female students. Based on the normalized gain percentage in Table 9 and the results of the Mann-Whitney test in Table 11, it can be concluded that there was no significant difference improvement in critical thinking skills between male and female students. In other words, in improving student's critical thinking skills, there was no significant difference in effect based on gender differences.

The results of critical thinking skills improvement based on gender that is relatively similar between male and female students are natural. Previous studies based on gender differences have varied results, including (1) superior to male students (Chen, Huang, \& Chou, 2016; Suherman et al., 2018), (2) superior to female students (Nurmaliah, 2009; Liliana \& Lavinia, 2011; Ramdiah, 2013) and (3) the result is the same (Thompson, et al., 2000; Çimer, et al., 2013; Nunaki et al., 2019). This difference in results is possible due to various factors, including social factors (interaction with friends, economics, etc.), emotional factors (anxiety, motivation, etc.), intellectual factors (learning style, intelligence quotient, etc.), pedagogical factors (methods, learning media, lecturers, etc.), or differences in many samples. In this study there is a possibility that there are differences in the number of samples, there are 23 male students and 101 female students, this is because it is related to the previously selected learning groups so that it needs to be studied in many balanced samples in the future.

Based on the learning model and gender, the improvement of students' critical thinking skills in Problem-based Learning and Mathematical Problem Posing is still in the medium category. Based on these results, to obtain better improvement, it is recommended that Problem-based Learning and Mathematical Problem Posing be applied over a longer-term (Masek \& Yamin, 2011) and be carried out consistently by providing facilities for student activities that support the development of critical thinking skills indicators.

\section{CONCLUSION AND SUGGESTION}

Based on the findings and discussion, there are conclusions as follows: in improving student's critical thinking skills (1) Problem-based Learning and Mathematical Problem Posing provide better effect than conventional learning, (2) there was no significant difference in effect between Problem-based Learning and Mathematical Problem Posing, and (3) there was no significant difference in effect based on gender differences.

The improvement of students' critical thinking skills is still in the medium category, to obtain better improvement, it is suggested that Problem-based Learning and Mathematical Problem Posing be applied over a longer-term and be carried out consistently by providing student activities facilities that support the development of critical thinking skills indicators. 


\section{ACKNOWLEDGEMENT}

The author would like to thank Direktorat Riset dan Pengabdian Masyarakat (DRPM) from Kementerian Ristek Dikti Indonesia for funding this research through the "skim penelitian disertasi doktor" program.

\section{REFERENCES}

Alrahlah, A. (2016). How effective the problem-based learning (PBL) in dental education. A critical review. The Saudi Dental Journal, 28, 155-161. https://doi.org/10.1016/j.sdentj.2016.08.003.

Asyari, M., Al Muhdhar, M. H. I., Susilo, H., \& Ibrohim. (2016). Improving critical thinking skills through the integration of problem based learning and group investigation. International Journal for Lesson and Learning Studies, 5(1), 36-44. https://doi.org/10.1108/IJLLS-10-2014-0042.

Azizmalayeri, K., MirshahJafari, E., Sharif, M., Asgari, M., \& Omidi, M. (2012). The impact of guided inquiry methods of teaching on the critical thinking of high school students. Journal of Education and Practice, 3(10), 42-47.

Barrett, T., MacLabhrainn, I., \& Fallon, H. (2005). Handbook of enquiry and problem based learning: Understanding problem based learning. Ireland: Centre for Excellence in Learning and Teaching, NUI Galway.

Bonotto, C. (2013). Artifacts as sources for problem-posing activities. Educational Studies in Mathematics, 83(1), 37-55.

Brown, S. I., \& Walter, M.I . (2005). The art of problem posing. London: Lawrence Erlbaum Associates Publishers.

Chen, C. M., \& Chang, C. C. (2014). Mining learning social networks for cooperative learning with appropriate learning partners in a problem-based learning environment. Interactive Learning $\quad$ Environments, 22(1), 97-124. https://doi.org/10.1080/10494820.2011.641677.

Chen, S., Huang, C. C., \& Chou, T.-L. (2016). The effect of metacognitive scaffolds on low achievers' laboratory learning. International Journal of Science and Mathematics Education, 14(2), 281-296.

Çimer, A., Timuçin M., \& Kokoç, M. (2013). Critical thinking level of biology classroom survey: CTLOBICS. The Online Journal of New Horizons in Education, $3(1), 15-24$.

Cohen, L., Manion, L., \& Morrison, K. (2007). Research methods in education. Madison Avenue, New York: Routledge.

Dwyer, C. P., Hogan, M. J., \& Stewart, I. (2014). An integrated critical thinking framework for the $21 \mathrm{st}$ century. Thinking Skills and Creativity, 12, 43-52. https://doi.org/10.1016/j.tsc.2013.12.004. 
English, L. D. (1997). Promoting a problem posing classroom. Teaching Children Mathematics, 4, 172-180.

Fajrianthi, F., Hendriani, W., \& Septarini, B. G. (2016). Pengembangan tes berpikir kritis dengan pendekatan item response theory. Jurnal Penelitian dan Evaluasi Pendidikan, 20(1), 45-55.

FitzPatrick, B., \& Schulz, H. (2015). Do curriculum outcomes and assessment activities in science encourage higher order thinking? Canadian Journal of Science, Mathematics and Technology Education, 15(2), 136-154. https://doi.org/10.1080/14926156.2015.1014074.

Gholami, M., Moghadam, P. K., Mohammadipoor, F., Tarahi, M. J., Sak, M., Toulabi, T., \& Pour, A. H. H. (2016). Comparing the effects of problem-based learning and the traditional lecture method on critical thinking skills and metacognitive awareness in nursing students in a critical care nursing course. Nurse Education Today, 45, 16-21. https://doi.org/10.1016/j.nedt.2016.06.007.

Gleason, N. W. (2018). Higher education in the era of the fourth industrial revolution. Springer. https://doi.org/10.1007/978-981-13-0194-0_1.

Gorghiu, G., Drăghicescu, L. M., Cristea, S., Petrescu, A.-M., \& Gorghiu, L. M. (2015). Problem-based learning - an efficient learning strategy in the science lessons context. Procedia-Social and Behavioral Sciences, 191, 1865-1870. https://doi.org/10.1016/j.sbspro.2015.04.570.

Hake, R. R. (1998). Interactive-engagement versus traditional methods: A six-thousandstudent survey of mechanics test data for introductory physics courses. American Journal of Physics, 66(1), 64-74.

Juano, A., \& Pardjono, P. (2016). Pengaruh pembelajaran problem posing terhadap kemampuan berpikir kritis dan komunikasi matematis siswa kelas V SD. Jurnal Prima Edukasia, 4(1), 46-53.

Liliana, C., \& Lavinia, H. (2011). Gender differences in metacognitive skills. A study of the 8th grade pupils in Romania. Procedia-Social and Behavioral Sciences, 29, 396401.

Mahanal. S. (2012). Strategi Pembelajaran Biologi, Gender dan Pengaruhnya Terhadap Kemampuan Berpikir Kritis. Prosiding Seminar Nasional UNS. 9(1).

Mahmuzah, R., Ikhsan, M., \& Yusrizal (2014) Peningkatan Kemampuan Berpikir Kritis dan Disposisi Matematis Siswa SMP dengan Menggunakan Pendekatan Problem Posing. Jurnal Didaktik Matematika, 1(2), 43-53.

Masek, A., \& Yamin, S. (2011). The effect of problem based learning on critical thinking ability: a theoretical and empirical review. International Review of Social Sciences and Humanities, 2(1), 215-221 
Nunaki, J. H., Damopolii, I., Kandowangko, N. Y., \& Nusantari, E. (2019). The effectiveness of inquiry-based learning to train the students' metacognitive skills based on gender differences. International Journal of Instruction, 12(2), 505-516. https://doi.org/10.29333/iji.2019.12232a.

Nurmaliah, C. (2009). Analisis keterampilan metakognisi siswa SMP Negeri di Kota Malang berdasarkan kemampuan awal, tingkat kelas, dan jenis kelamin. Jurnal Biologi Edukasi, 1(2), 18-21.

Paul, R., \& Elder, L. (2014). Critical Thinking: Tools for taking charge of your professional and personal life. Retrieved from http://ptgmedia.pearsoncmg.com/images/9780133115284/samplepages/0133115283.pdf.

Perkins, C., \& Murphy, E. (2006). Identifying and measuring individual engagement in critical thinking in online discussions: An exploratory case study. Educational Technology \& Society, 9, 298-307.

Ramdiah, S. (2013). Pengaruh strategi pembelajaran PQ4R terhadap keterampilan metakognitif dan hasil belajar biologi siswa putra dan putri kelas XI SMA di Kota Banjarmasin. In Proceeding Biology Education Conference: Biology, Science, Enviromental, and Learning, 10, 96-102.

Ramdiah, S., \& Corebima, A.D. (2014). Learning strategy equalizing student's achievement metacognitive, and critical thinking skills. American Journal of Educational Research, 2(8), 577-584.

Ricketts, J. C., \& Rudd, R. (2004). Critical thinking skills of FFA leaders. Journal of Southern Agricultural Education Research, 54(1), 7-20.

Rosli, R., Capraro, M. M., \& Capraro, R. M. (2014). The effects of problem posing on student mathematical learning: A meta-analysis. International Education Studies, 7(13), 227-241.

Samejima, M., Hisakane, D., \& Komoda, N. (2015). Automatic annotation method on learners' opinions in case method discussion. Interactive Technology and Smart Education, 12(2), 90-99. https://doi.org/10.1108/ITSE-04-2015-0003.

Saputra, M. D., Joyoatmojo, S., Wardani, D. K., \& Sangka, K. B. (2019). Developing critical-thinking skills through the collaboration of jigsaw model with problem-based learning model. International Journal of Instruction, 12(1), 1077-1094. https://doi.org/10.29333/iji.2019.12169a.

Şendağ, S., \& Ferhan Odabaşi, H. (2009). Effects of an online problem based learning course on content knowledge acquisition and critical thinking skills. Computers and Education, 53, 132-141. https://doi.org/10.1016/j.compedu.2009.01.008.

Schoenberger-Orgad, M., \& Spiller, D. (2014). Critical thinkers and capable practitioners. Journal of Communication Management, 18(3), 210-221. https://doi.org/10.1108/JCOM-11-2012-0085. 
Schechter, C. (2011). Switching cognitive gears problem-based learning and successbased learning as instructional frameworks in leadership education. Journal of Educational Administration, 49(2), 143-165. https://doi.org/10.1108/09578231111116707.

Silver, E. (1994). On mathematical problem posing. For the Learning of Mathematics, 14(1), 19-28.

Silver, E. A (2013). Problem-posing research in mathematics education: looking back, looking around, and looking ahead. Educational Studies in Mathematics, 83, 157-162.

Suarsana, I. M., Lestari, I. A. P. D., \& Mertasari, N. M. S. (2019). The effect of online problem posing on students' problem-solving ability in mathematics. International Journal of Instruction, 12(1), 809-820. https://doi.org/10.29333/iji.2019.12152a.

Suherman, D. P., Purwianingsih, W., \& Diana, S. (2018). The analysis of self-efficacy and metacognitive and its relation with academic performance of high school students based on gender on genetics concept. Assimilation: Indonesian Journal of Biology Education, 1(1), 14-20.

Susilo, B. E., Darhim, D., \& Prabawanto, S. (2018). Supporting activities for critical thinking skills development based on students' perspective. Paper presented of the $1 s t$ International Conference on Science and Technology for an Internet of Things. European Alliance for Innovation (EAI).

Susilo, B. E., Darhim, D., \& Prabawanto, S. (2019). Students critical thinking skills toward concepts differences in finding area of a plane region and definite integral. Unnes Journal of Mathematics Education, 8(1), 1-7. https://doi.org/10.15294/ujme.v8i1.29463.

Thompson, P. M., Giedd, J. N., Woods, R. P., MacDonald, D., Evans, A. C., \& Toga, A. W. (2000). Growth patterns in the developing brain detected by using continuum mechanical tensor maps, Nature, 404(1), 190-193. https://doi.org/10.1038/35004593.

Trilling, B., \& Fadel, C. (2009). 21 st century skills learning for life in our times. San Francisco: Jossey-Bass.

Vong, S. A., \& Kaewurai, W. (2017). Instructional model development to enhance critical thinking and critical thinking teaching ability of trainee students at regional teaching training center in Takeo Province, Cambodia. Kasetsart Journal of Social Sciences, 38, 88-95. https://doi.org/10.1016/j.kjss.2016.05.002.

Widiawati, L., Joyoatmojo, S., \& Sudiyanto. (2018). Higher order thinking skills as effect of problem based learning in the 21st century learning. International Journal of Multicultural and Multireligious Understanding, 5(3), 96-105. 